\title{
The Definition of Affordable Luxury Based on Consumer Perception
}

\author{
Lunan Zhao \\ Business School \\ Beijing Institute of Fashion Technology \\ Beijing, China \\ 1056812737@qq.com
}

\author{
Shui Jin* \\ Fashion Communication School \\ Beijing Institute of Fashion Technology \\ Beijing, China \\ jinshui@126.com \\ * Corresponding Author
}

\begin{abstract}
In recent years, "Affordable Luxury" often appears in public vision. Due to rapid expansion and rising sales of affordable luxury brands in recent years, people are no longer strangers to affordable luxury goods. Therefore, many experts and scholars began to pay attention to the affordable luxury brand. Some experts and scholars study the marketing mode and channel analysis of this. But seldom scholars study the definition of affordable luxury. The purpose of this paper is to examine the definition of affordable luxury based on consumer perception through semi-structured deep interview.
\end{abstract}

Keywords—affordable luxury; luxury; definition;deep interview

\section{INTRODUCTION}

At first, affordable luxury appeared as an entry-level luxury to cater to the consumer. And later, affordable luxury slowly filled the gap between ordinary and luxury goods. For people with low incomes and high stylish tastes, the price of luxury is unimaginable, and affordable luxury treats this group as the target consumer group. Current affordable luxury brands mainly include luxury brand vice line, style brands and original designer brands.

Affordable luxury brands rapidly develop in the past five years. The luxury market enters the freezing point in 2012. First-line luxury brands began to find other ways. Some firsttier brands pioneered to develop their own secondary brands such as Miu Miu, a vice line brand of Prada; Emporio Armani, a vice line brand of Giorgio Armani; MARC JACOBS, a vice line brand of MARC BY MARC JACOBS, and DKNY, a vice line brand of Donna KAREN. By creating its own line of affordable luxury brand to expand the consumer market, this strategy has been a good market response[1].

The number of the middle class in our country is huge, and the number of the middle class is still on the rise. China will be a huge market for affordable luxury brands. According to the data of TABLE 1, Business Intelligence Network in 2016, it can be seen from the market share comparison between luxury groups and affordable luxury groups that the affordable luxury brands will have broad space for development in China. Coach pays more attention to the Chinese market; its market share in China is relatively large. Michael Kors and Kate Spade have not really developed the Chinese market.
TABLE I. REPRESENTATIVE BRANDS MARKET SHARE COMPARISON

\begin{tabular}{|c|c|c|c|}
\hline Classification & $\begin{array}{c}\text { Company } \\
\text { name }\end{array}$ & Area & $\begin{array}{c}\text { Market } \\
\text { share }\end{array}$ \\
\hline \multirow{6}{*}{ Lurxury group } & \multirow{3}{*}{ Kering } & Asia (excluding Japan) & $35 \%$ \\
\hline & & Europe & $37.4 \%$ \\
\hline & & North America & $22.9 \%$ \\
\hline & \multirow{3}{*}{ LVMH } & Asia (excluding Japan) & $27 \%$ \\
\hline & & Europe & $26.2 \%$ \\
\hline & & United States & $18 \%$ \\
\hline \multirow{7}{*}{$\begin{array}{l}\text { Affordable } \\
\text { Luxury }\end{array}$} & \multirow{2}{*}{ Coach } & Greater China & $14.5 \%$ \\
\hline & & United States & $55.2 \%$ \\
\hline & \multirow{3}{*}{ Michael Kors } & Asia (excluding Japan) & $2.3 \%$ \\
\hline & & Europe & $21.0 \%$ \\
\hline & & North America & $74.4 \%$ \\
\hline & \multirow{2}{*}{ Kate Spade } & United States & $81.5 \%$ \\
\hline & & Others & $18.5 \%$ \\
\hline
\end{tabular}

* China Business Intelligence Network

Many experts and scholars pay attention to the marketing mode and channel analysis of affordable luxury brand, but seldom scholars study the definition of affordable luxury. This study uses qualitative research methods such as semistructured depth interviews. The purpose of this paper is to study the definition of luxury products and brands in the minds of consumers. Carefully analyze consumer's understanding of affordable luxury. The semi-structured open questions and answers can help to know consumers' real thoughts.

\section{THE STUDY OF AFFORDABLE LUXURY’s DEFINITION}

\section{A. Determine Research Method}

Semi-structured deep interviews are one of the most suitable research methods for this study.

\section{B. Research Object}

The steps of selecting the research object are as follows.
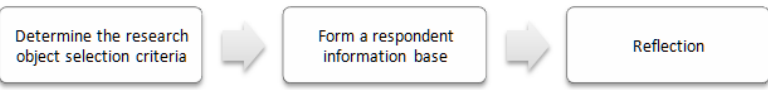

Fig. 1. Example of a figure caption. 
1) The selection criteria of research object goods.

a) Consumers who have purchased affordable luxury

b) Consumers who willing to share shopping experience with active cooperation.

c) Consumers who agreed to record and allowing researchers to write relevant information.

2) respondent information base

The researchers selected six consumers and two experts for in-depth interviews. In order to make the research more convincing, these six consumers have different ages, occupations and salaries. In addition, in-depth interviews with two experts also increased the depth of this research. The following is the respondent database.

TABLE II. THE RESPONDENT DATABASE

\begin{tabular}{|c|c|c|c|c|c|}
\hline \multicolumn{6}{|c|}{ Consumer } \\
\hline Name & Gender & Age & \multicolumn{2}{|c|}{ Work } & $\begin{array}{c}\text { Monthly } \\
\text { income }(R M B)\end{array}$ \\
\hline $\mathrm{LT}$ & Famale & 24 & \multicolumn{2}{|c|}{$\begin{array}{c}\text { Product Operations } \\
\text { Manager }\end{array}$} & $10,000-12,000$ \\
\hline TS & Famale & 25 & \multicolumn{2}{|c|}{$\begin{array}{c}\text { Product Operations } \\
\text { Assistant }\end{array}$} & $6,000-8,000$ \\
\hline ZMY & Male & 30 & \multicolumn{2}{|c|}{$\begin{array}{c}\text { Product Operations } \\
\text { Manager }\end{array}$} & $12,000-18,000$ \\
\hline $\mathrm{XB}$ & Famale & 39 & \multicolumn{2}{|c|}{ High School Teacher } & $5,000-6,000$ \\
\hline $\mathrm{ZY}$ & Famale & 25 & \multicolumn{2}{|c|}{ Administrative Assistant } & $6,000-8,000$ \\
\hline $\mathrm{XN}$ & Famale & 24 & \multicolumn{2}{|c|}{ Marketing Assistant } & $8,000-10,000$ \\
\hline \multicolumn{6}{|c|}{ Experts } \\
\hline Name & Gender & \multicolumn{2}{|r|}{ Title } & \multicolumn{2}{|c|}{$\begin{array}{c}\text { Profession } \\
\end{array}$} \\
\hline JS & Male & \multicolumn{2}{|c|}{$\begin{array}{l}\text { Associate } \\
\text { Professor }\end{array}$} & \multicolumn{2}{|c|}{$\begin{array}{l}\text { Art Design } \\
\text { Fashion brand management } \\
\text { Cultural and creative industry } \\
\text { management }\end{array}$} \\
\hline WQY & Famale & \multicolumn{2}{|c|}{$\begin{array}{l}\text { Associate } \\
\text { Professor }\end{array}$} & \multicolumn{2}{|c|}{$\begin{array}{l}\text { Luxury management } \\
\text { Marketing } \\
\text { Consumer Behavior }\end{array}$} \\
\hline
\end{tabular}

\section{3) Reflection}

After the sampling was completed, the researchers found that interviewees were between 20 and 40 years old, and were mostly female consumers. Their monthly income is between 5000 and 18000. The researchers believe that this age group and income levels basically in line with the target population of affordable luxury. Sample quantity and structure are reasonable.

\section{Interview Outline}

This study uses in-depth interviews with semi-structured, so the problems of interviews designed are basically open issues around with the definition of affordable luxury, and will be appropriately expanded according to the interviewees' responses.

\section{Interview Process}

Before the interview begins, the researcher will make an appointment with the interviewee about the time and location, and the interview will not be interrupted. Interview time is more than 20 minutes. The whole process is recorded.

\section{E. Date Collation}

After the interview process was over, the researcher completely converted the interviewee's voice data into written materials. After repeated careful reading, extract key words. The researchers kept the keywords that appeared frequently as important conclusions, and then analyzed less frequently appeared keywords and consider whether to delete them. The following is the result of in-depth interview.

1) Interviewee's understanding for affordable luxury goods: After data integration, the following keywords appeared more frequently: The middle class, Quality of life, Non-essential items, 20-40 years old, Good design process, Young. The following is less appeared but still reserved keywords: Brand heat, Petty bourgeois sentiment, Taste.

2) The typical affordable luxury brands that interviewees know? Price and purchase channels?[2]: To change the default, adjust the template as follows.

TABLE III. DATE INTEGRATION

\begin{tabular}{|c|c|c|c|}
\hline Classification & Typical Brands & Price(RMB) & $\begin{array}{l}\text { Purchase } \\
\text { channels }\end{array}$ \\
\hline Bags & $\begin{array}{l}\text { COACH, MK, TUMI, } \\
\text { KATE SPADE, } \\
\text { MICHAEL KORS }\end{array}$ & $1,500-6,000$ & \multirow{4}{*}{$\begin{array}{l}\text { Online } \\
\text { shopping, } \\
\text { physical stores, } \\
\text { duty-free } \\
\text { shops, buy on } \\
\text { sb.'s behalf }\end{array}$} \\
\hline Clothing & $\begin{array}{c}\text { MIUMIU, } \\
\text { GIORGIO ARMANI, } \\
\text { POLO RALPH LAUREN, } \\
\text { TOMMY HILFIGER }\end{array}$ & $500-4,000$ & \\
\hline Accessories & $\begin{array}{l}\text { TIFFANY,APM,CK, } \\
\text { SWAROVSKI }\end{array}$ & $500-2,500$ & \\
\hline Others & KAIYODO,TAMIYA & $500-8,000$ & \\
\hline
\end{tabular}

3) Affordable luxury target consumer groups: The answer from respondents are more in line, the target population characteristics described as: 20-40 years old, monthly salary on top of 6,000 yuan, above white-collar workers, the pursuit of quality of life.

4) Purchase Frequency: Consumers with higher incomes and longer working years are more likely to buy affordable luxury goods more than once per month. Consumers with lower income buy affordable luxury about once a quarter on demand[3].

5) Purchase Motivation: The factors that respondents were most concerned about affordable luxury products were well designed, high quality, affordable price. Almost every interviewee mentioned these three points.

6) Consumer awareness of China's local affordable luxury brands: When referring to this question, four interviewees answered unclearly and did not know it. One interviewee replied that she was not interested in the domestic affordable luxury brands. Another respondent is not sure about the answer. She thought the brands that price more suitable for affordable luxury include: ClothScenery, Yen Cha, Herborist, Maruyama and others.

7) Differences between local affordable luxury brands and foreign luxury brands: The design is not fashionable, the quality process is not high, the popularity is not high. 


\section{ANALYSIS OF RESEARCH RESULTS}

\section{A. The Definition of Affordable Luxury}

According to the survey, the definition of affordable luxury is as follows: Non-essential consumer goods which can compare with luxury in quality and design, but is less scarcity and expensive than luxury goods, can reflect the quality and taste of life.

\section{B. The Characteristics of Affordable Luxury}

According to the interview data collation results, affordable luxury goods have those characteristics: Good design, Detailed process, Expensive but not extravagant, Fashion, Personality.

\section{Target Population}

The target population of Affordable luxury: 20-40 years old, white-collar workers above the class, someone who pursues individuality and fashion. Consumers who buy affordable luxury products in China are divided into two categories: one is the daily consumption from the affluent class. They are more concern about the quality of life, and less concerned about the price. They like to embody social status; another one is a rapidly growing mass consumer group with lifestyle tastes, fashion and personality but limited purchasing power.

\section{Why Affordable Luxury Can Get Consumers Favor?}

1) Novel design:Affordable luxury brands mainly include the luxury brand vice line, style brand and original designer brand. The merchandise of the luxury brand vice line are generally designed by the first-line brand designers. Style brand and original designer brand attaches great importance to product design. So affordable luxury products can ensure a high level in the design. Consumers can find products that match their individuality.

2) High-quality craftsmanship:One of the flagships of luxury brands is high quality. This feature allows the middle class to experience the quality of luxury goods.

3) The price is reasonable:The price is reasonable. Affordable luxury product prices are generally below 5,000 yuan. The purchasing power of the public consumers can afford to buy affordable luxury products. In addition, the money which buys a luxury product can buy a few pieces of affordable luxury products[4].

4) There are many sales channels for affordable luxury brands:From a variety of online and offline channels to expand, consumers can easily access to affordable luxury goods. Through the online website, consumers can learn the latest brand information. They can also go to the offline store for experiential consumption.

5) The media exposure is high:Through advertising or endorsement can effectively increase the affordable luxury brand exposure. Affordable luxury brand invested heavily in advertising and endorsements[5].
6) consumers have a higher brand loyalty:Consumers have a higher brand loyalty. After consumers buy affordable goods in line with their own personality, they will be a repeat of the purchase. And, consumers with some brand loyalty will recommend others to buy.

\section{E. China's Local Affordable Luxury Brand Situation}

China has some local affordable luxury brands, but we found that awareness and recognition of China's local affordable luxury brands are not high. The comparison of local affordable luxury brands and foreign affordable luxury brands:

1) Differences in design style:Due to differences in culture, region and other aspects, they are different in design style. The difference between Chinese and other people in body shape, color, lifestyle and ethnic characteristics will lead to aesthetic differences. In this regard, China's domestic brands have certain advantages. They know more about Chinese tastes. Second is the difference in the design level. The design of Chinese local brands is limited to the stereotype of Chinese elements in a way. For consumers who pursue fashion and individuality, they will choose foreign products in first.

2) Differences in quality:Cultural of the local domestic brands have not been accumulated for a long time. The gap of quality between domestic brands and foreign affordable luxury brands is relatively large.

3) The pricing is basically the same.

4) Differences in customers' approval degree:There are many fake and shoddy products on the Chinese market. Consumers lose confidence in Chinese local brands.

\section{CONCLUSION}

This paper interviewed six consumers and two experts through a semi-structured interview. First, we took a closer look about their understanding of affordable luxury goods. Then, through data collation, we summed up the definition and basic characteristics of affordable luxury, and analyzed the ideas put forward by consumers during the interview. The thinking on the definition of affordable luxury products has led to the thinking about the comparison between domestic affordable luxury brands and foreign affordable luxury brands.

\section{ACKNOWLEDGMENT}

I would like to express my heartfelt gratitude to my tutor, associate professor Jin Shui, for his constant encouragement and guidance. He has walked me through all the stages of the writing of this thesis. Without his consistent and illuminating instruction, this thesis could not have reached its present form.

\section{REFERENCES}

[1] Belinda Dewsnap, Cathy Hart.Category management: a new approach for fashion marketing?[J]. European Journal of Marketing, 2004(38):809-834.

[2] Poel.D.V.Sehamphelaere.J.D. and Wets.G..Direct and indirect effects of retail promotions on sales and profits in the do it yourself market[J].Expert Systems with Applieations, 2004(27):53-62. 
[3] Raju.J.S. The effect of price promotions on variability in product category sales[J]. Marketing Science, 1992(11):207-220.

[4] Fader.P.and Lodish.L.M. Across - category analysis of category structure and promotional activity for grocery products[J].Journal of Marketing, 2000(54):2-56.
[5] Narasimhan.C., Neslin.S.A.and Sen.s.. Promotional elasticities and category characteristics[J]. Journal of Marketing, 1999(6):17-30. 